\title{
Manganese and limestone interactions during mine water treatment
}

\author{
A.M. Silva, F.L.S. Cruz, R.M.F. Lima, M.C. Teixeira, V.A. Leão* \\ BioEHHdrometallurgy Laboratory - Universidade Federal de Ouro Preto., Campus Morro do Cruzeiro, Ouro Preto, MG, 35400-000, Brazil
}

\section{A R T I C L E I N F O}

\section{Article history:}

Received 24 September 2009

Received in revised form 8 May 2010

Accepted 10 May 2010

Available online 16 May 2010

\section{Keywords:}

Manganese

Limestone

Mine waters

ATR-IR

Acid mine drainage

\begin{abstract}
A B S T R A C T
Manganese removal from mining-affected waters is an important challenge for the mining industry. Addressed herein is this issue in both batch and continuous conditions. Batch experiments were carried out with synthetic solutions, at $23 \pm 2{ }^{\circ} \mathrm{C}$, initial pH 5.5 and $8.3 \mathrm{~g}$ limestone/L. Similarly, continuous tests were performed with a $16.5 \mathrm{mg} / \mathrm{L} \mathrm{Mn}^{2+}$ mine water, at $23^{\circ} \mathrm{C}$, initial pH 8.0 and $20.8 \mathrm{~g}$ limestone/L. Calcite limestone gave the best results and its fine grinding proved to the most effective parameter for manganese removal. In either synthetic solutions or industrial effluents, the final manganese concentration was below $1 \mathrm{mg} / \mathrm{L}$. A change in limestone surface zeta potential is observed after manganese removal and manganese carbonate formation was suggested by IR spectroscopy. The conclusion is that limestone can remove manganese from industrial effluents for values that comply with environmental regulations.
\end{abstract}

(c) 2010 Elsevier B.V. All rights reserved.

\section{Introduction}

The removal of manganese and sulfate from mining-affected water is a important challenge for water management in the mining industry, as theses specie are not solely removed by $\mathrm{pH}$ control. Manganese is an important trace element for the functioning and activation of many enzymes (manganese superoxide dismutase, kinases, decarboxylases, among others) in the human body, but at high levels, it can cause damage to the brain, liver, kidneys and nervous system [1]. As a consequence, many environmental agencies throughout the world have regulated limits for manganese concentration in water. For instance, the USEPA has set the level of manganese in drinking water at $0.05 \mathrm{mg} / \mathrm{L}$. Similarly, its maximum level, according to the Brazilian legislation, is 0.01 and $1 \mathrm{mg} / \mathrm{L}$ for surface water and wastewater, respectively.

Manganese removal from wastewater depends on: the concentration and speciation encountered in the effluent; the volume of wastewater to be treated and economical aspects. In addition to manganese, mine water usually contains a series of other elements such as iron, aluminum, copper, and zinc [2] and most of these metals can be removed by increasing the $\mathrm{pH}$; while iron is readily precipitated through oxidation to the trivalent state using either active or passive systems. Manganese can also be removed by oxidation, since $\mathrm{Mn}(\mathrm{IV})$ compounds are insoluble. Notwithstanding, manganese (II) is soluble over a wide $\mathrm{pH}$ range. Its chemical oxida-

\footnotetext{
* Corresponding author. Tel.: +55 313559 1102; fax: +55 3135591561 .

E-mail addresses: versiane@demet.em.ufop.br, va.leao@uol.com.br, adarlenems@gmail.com (V.A. Leão).
}

tion is kinetically slow [3], and due to the high reduction potential of $\mathrm{Mn}(\mathrm{IV})$, parallel reactions, such as organic matter and $\mathrm{Fe}(\mathrm{II})$ oxidation, induces excessive oxidant consumption. Therefore, iron removal is required prior to manganese oxidation [4]. The use of biological processes involving manganese (II) oxidation [3,5] is an alternative treatment for manganese-affected water.

Carbonate sources such as limestone can be successfully applied for manganese removal, since they are inexpensive, effective [6,7] and widely available. This method has been widely used as an alternative for treating contaminated drinking water [8-10] and also for treating acid mine drainage (AMD) [11]. More than $80 \%$ of the heavy metals, such as: copper, iron, manganese, cadmium and others can be removed using either batch or continuous-flow limestone filtration processes [12]. Aziz and Smith [8,13] studied manganese removal $(1 \mathrm{mg} / \mathrm{L})$ from drinking water using different solid media such as limestone, brick powder and gravel in both batches and in columns. Out of the three materials, limestone showed the best results with more than $95 \% \mathrm{Mn}$ (II) removal. Similarly, Thornton [10] and Rose et al. [14] have shown that limestone can be applied with relative success to remove manganese from acid mine drainage, although limestone beds are not the best option because they are usually clogged with organic matter (algae, leaves), silt, Fe- and Al-hydroxides and gypsum, among others.

Although metal carbonate formation seems obvious when applying limestone to the treatment of manganese-affected water, such compounds have seldom been identified, especially during the treatment of AMD. One of these species was kutnahorite, CaMn $\left(\mathrm{CO}_{3}\right)_{2}$, which is thermodynamically stable in such waters, provided $\mathrm{Ca}^{2+}$ is available $[4,15]$. Due to the complexity of the different processes occurring during the passive treatment of 
Table 1

Chemical analysis of the limestone samples.

\begin{tabular}{lll}
\hline Limestone & Ca (\%) & $\mathrm{Mg}(\%)$ \\
\hline Calcite I & 42.8 & 0.14 \\
Calcite II & 39.7 & 0.23 \\
Dolomite & 26.2 & 7.68 \\
\hline
\end{tabular}

AMD (wetlands), manganese removal as oxyhydroxides derived from either abiotic or biotic Mn(II) oxidation has been proposed. Manganese oxyhydroxides $(\mathrm{MnOOH})$ were noticed in reactors containing different substrates (dolomite, magnesite, limestone, quartzite) [16], while nearly $90 \%$ of the manganese present in a carbonate precipitate from an AMD pond was in the form of oxides [15].

Seeking to shed new light on the role of limestone in manganese removal, the use of fine ground limestone powder as a cost-effective, simple alternative to remove manganese from mining-affected water was studied. An attempt to characterize the manganese removal mechanism was also carried out using zeta potential and infrared spectroscopy.

\section{Materials and methods}

Calcite and dolomite limestone samples were kindly provided by Brazilian producers. These samples were dry-sieved or alternatively dry-ground in a vibrating cup mill (Pulverisette 9, Fritsch) to produce particle size distributions with different $\mathrm{d}_{50}$ values. These particle size distributions were assessed by laser diffraction (Mastersize, 2000E). Chemical analysis (ICP-OES, Spectro) was also performed on all limestone samples to determine their nature. Table 1 presents the chemical analysis of three different samples showing their calcium and magnesium content, so that the composition of the limestone could be defined, i.e. dolomite limestone presents higher than $5 \%$ magnesium, while calcite limestone has less than $5 \%$ magnesium content. In addition, the limestone nature was confirmed by XRD analysis (Shimadzu XRD 6000).

The effects of both calcite and dolomite limestone as well synthetic $\mathrm{CaCO}_{3}$ on manganese removal were assessed in both batch and continuous experiments. Batch manganese removal was assessed with $120 \mathrm{~mL}$ synthetic $\mathrm{Mn}^{2+}$ solutions $\left(\mathrm{MnCl}_{2} \cdot 4 \mathrm{H}_{2} \mathrm{O}\right.$, Synth) stirred with limestone powder in capped erlenmeyer (250 mL capacity) flasks in an orbital shaker at $350 \mathrm{~m}^{-1}$ and $23 \pm 2{ }^{\circ} \mathrm{C}$, for 60 or $90 \mathrm{~min}$. Unless otherwise stated, a $8.3 \mathrm{~g} / \mathrm{L}$ pulp density and initial $\mathrm{pH}=5.5$ were applied throughout the experiments. At the end of the experiment, the $\mathrm{pH}$ was measured (it reached values around 9.0), the pulp was filtered and the manganese concentration in the aqueous phase was determined by atomic absorption spectrometry (AAS) (Perkin Elmer AAnalisty 100). The manganese removal efficiency was determined by mass balance.

Continuous experiments were carried out in a $1.64 \mathrm{~L}$ capacity MSMPR reactor, at $23 \pm 2{ }^{\circ} \mathrm{C}$. The reactor was fed separately with (i) mine water and (ii) a pulp made up of limestone and distilled water to achieve a solid content of $20.8 \mathrm{~g} / \mathrm{L}$ limestone. After proper $\mathrm{pH}$ adjustment, both flows were pumped at $16.0 \mathrm{~mL} / \mathrm{min}$ (mine water) and $3.0 \mathrm{~mL} / \mathrm{min}$ (limestone pulp) into the reactor. Residence time was set at $60 \mathrm{~min}$ and the experiments ran for at least 12 residence times to ensure steady state conditions. After every $60 \mathrm{~min}$, an aliquot was withdrawn from the reactor, filtered and its manganese content was determined by Atomic Absorption spectrometry (AAS, Perkin Elmer AAnalyst 100), while the solid residue was preserved for further analysis (SEM-EDS, Infrared spectroscopy and zeta potential determination). The mine water was stored in plastic containers at room temperature and filtered prior to each

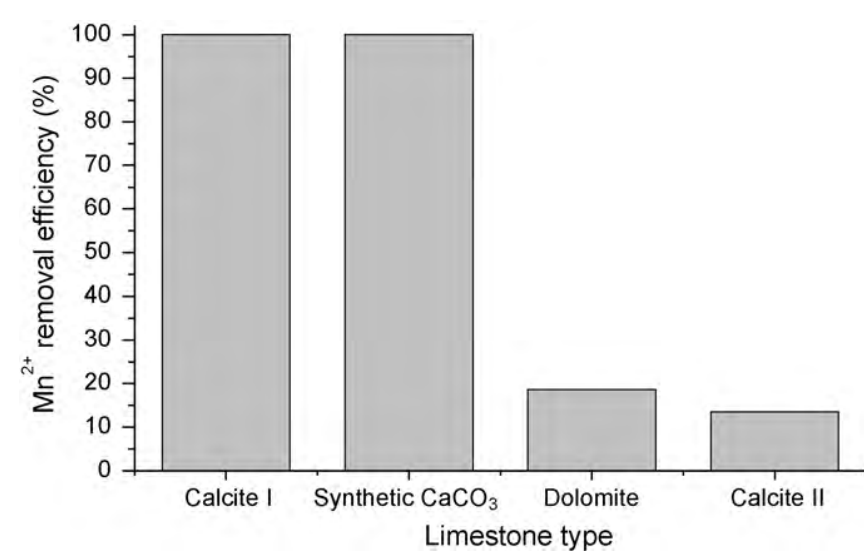

Fig. 1. Effect of limestone type on the removal of manganese in batch experiments. $60.0 \mathrm{mg} / \mathrm{L}$ initial manganese concentration; $8.3 \mathrm{~g} / \mathrm{L}$ limestone; initial $\mathrm{pH} 5.5$; $23 \pm 2{ }^{\circ} \mathrm{C}$, particle size: $<45 \mu \mathrm{m}$.

experiment. Its $\mathrm{pH}$ was adjusted with a $6 \mathrm{~mol} / \mathrm{L} \mathrm{NaOH}$ solution and the manganese content was determined by AAS $(16.5 \mathrm{mg} / \mathrm{L})$.

Scanning electron microscopy (SEM) was used to examine the morphology of limestone particles. The samples were coated with graphite by electro-deposition, using a Jeol JEE 4C instrument and analysed by a JEOL JSM 5510 scanning electron microscope (SEM), with an accelerating voltage $0.5-30 \mathrm{kV}$, equipped with a spectrometer for micro-analysis based on an energy dispersive X-Ray spectroscopy system (EDS).

FITR spectra were registered on a Nicolet Nexus 470 model spectrophotometer equipped with a Centarus microscope, an attenuated total reflectance (ATR) apparatus (Thermo) and a ZnSe internal reflection devise. Medium infrared measurements were produced with a $\mathrm{KBr}$ bean splitter and an $\mathrm{HgCdTe}$ detector. The samples were pressed against a flat glass surface and mounted under the ATR apparatus. The spectra were collected in the $400-4000 \mathrm{~cm}^{-1}$ region with a minimum of 32 scans at $4 \mathrm{~cm}^{-1}$ resolution.

After pulverizing the limestone samples $\left(d_{90}<10 \mu \mathrm{m}\right)$, zeta potential was assessed in a Zetasizer Nano ZS zetameter (Malvern). Prior to the readings, a $0.5 \%$ solid pulp was prepared with deionised water and limestone samples (one, before, and another, after mixing with a $60 \mathrm{mg} / \mathrm{L}$ Mn solution). Diluted $\mathrm{HCl}$ and $\mathrm{NaOH}$ solutions were used to control the $\mathrm{pH}$.

\section{Results and discussion}

The effect of limestone composition on manganese removal from a $60 \mathrm{mg} / \mathrm{L} \mathrm{Mn(II)} \mathrm{synthetic} \mathrm{solution} \mathrm{is} \mathrm{presented} \mathrm{in} \mathrm{Fig.} \mathrm{1,}$ for $<45 \mu \mathrm{m}$ particle size. The dolomite limestone removed $18.6 \%$ $\mathrm{Mn}(\mathrm{II})$, whereas the calcite limestones I and II removed $100 \%$ and $13.5 \% \mathrm{Mn}(\mathrm{II})$, respectively. The results achieved with these limestone samples are compared with that produced by a chemically precipitated $\mathrm{CaCO}_{3}$, where $100 \%$ removal was observed. When comparing dolomite and calcite limestone, the latter shows better performance. This is because powdered dolomite limestone is less reactive [6] than the calcite limestone and this is consistent with the results achieved for drains, designed for AMD treatment, constructed from limestone of different origins [11] and composition [17]. Furthermore, the particle size distribution of calcite limestone I shows a higher proportion of fine particles $(75 \%<20 \mu \mathrm{m})$ as compared to calcite limestone II $(20 \%<20 \mu \mathrm{m})$ which facilitates manganese removal (Fig. 2). Similarly, the high extraction observed with synthetic $\mathrm{CaCO}_{3}$ can be also ascribed to its low particle size $(100 \%<20 \mu \mathrm{m})$ and therefore higher surface area $\left(9.7 \mathrm{~m}^{2} / \mathrm{g}\right)$. These results are corroborated by those observed by Letterman et al. [18], 


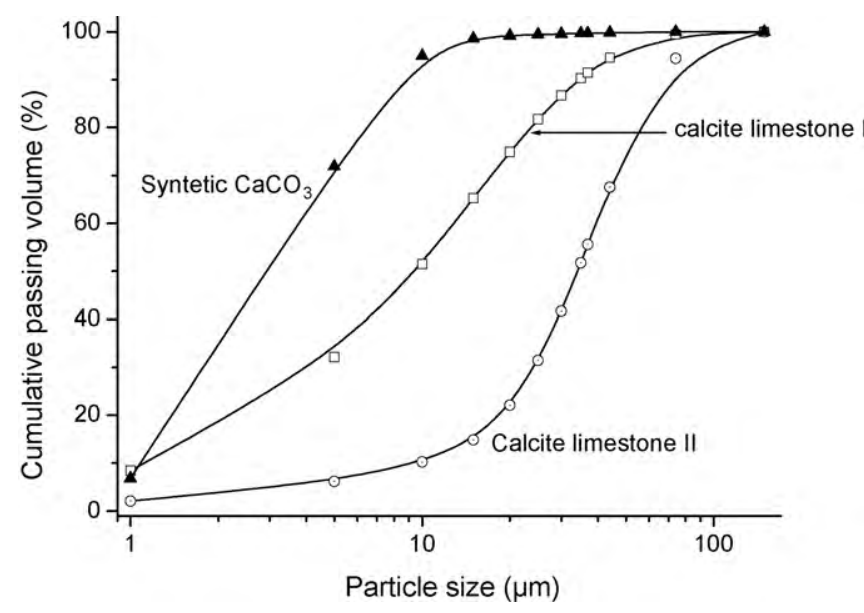

Fig. 2. Cumulative particle size distributions for calcite limestone of different origins and synthetic $\mathrm{CaCO}_{3}$ as applied in the batch experiments.

Potgieter-Vermaak et al. [19] and Sun et al. [20]. For the material that enabled high manganese removal, a pulp $\mathrm{pH}$ of 9.0 was the highest value attained, therefore suggesting that to some extent, limestone dissolution accounts for manganese removal [8]. As calcite limestone I showed the best results, it was selected for further experiments, being hereafter referred to as limestone.

After this selection, a series of experiments was performed to determine the effects of time, pulp density and initial $\mathrm{Mn}$ (II) concentration on manganese removal from a synthetic solution, at an initial pH of 5.5 (Fig. 3). Manganese removal with limestone is relatively fast with $100 \%$ extraction in $60 \mathrm{~min}$ (Fig. 3a) which is consistent with the work of Aziz and Smith [8]. In the present work, experiments carried out at $70^{\circ} \mathrm{C}$ removed manganese slightly slower than those at $23^{\circ} \mathrm{C}$, i.e. time and temperature have significant effects on manganese removal, as also observed by Ghaly et al. [16]. As expected, the higher the limestone content in the pulp, the higher the $\mathrm{pH}$ and the greater the manganese removal [16]. From a solution containing $60 \mathrm{mg} / \mathrm{L} \mathrm{Mn}(\mathrm{II})$, the removal increased with an increase in the limestone content up to $8.3 \mathrm{~g} / \mathrm{L}$ and levelled out above this value (Fig. 3b). Additionally, this $8.3 \mathrm{~g} / \mathrm{L}$ pulp density was able to remove manganese in the range of $0-155 \mathrm{mg} / \mathrm{L} \mathrm{Mn}$ (II) [14] (the latter represents the highest concentration usually found in mine waters) producing final effluents with manganese concentrations below $1 \mathrm{mg} / \mathrm{L}$. However, these results were not reproduced when experimenting with the mine water sample. No appreciable removal was observed at an initial $\mathrm{pH}$ of 5.5 and $42.6 \%$ manganese removal was accomplished using $8.3 \mathrm{~g} / \mathrm{L}$ limestone from a solution containing $16.5 \mathrm{mg} / \mathrm{L} \mathrm{Mn(II),} \mathrm{at} \mathrm{pH} 8.0$ (initial), producing a final effluent containing $8.0 \mathrm{mg} / \mathrm{L} \mathrm{Mn}^{2+}$ (Table 2). Therefore, the limestone content had to be increased to $20.8 \mathrm{~g} / \mathrm{L}$ to produce a final solution with manganese concentration below $1 \mathrm{mg} / \mathrm{L}$ and $\mathrm{pH} 8.8$.

Since powered limestone is not suitable for fixed bed column applications, continuous experiments were performed to assess manganese removal from the mine water (Fig. 4) on a $1.64 \mathrm{~L} \mathrm{MSMPR}$ reactor with $60 \mathrm{~min}$ residence time, at $23 \pm 2{ }^{\circ} \mathrm{C}$. In these experi-

Table 2

Effect of limestone content on manganese removal from mine water. Manganese (II) concentration: $16.5 \mathrm{mg} / \mathrm{L}$; particle size $<45 \mathrm{~mm}$; initial $\mathrm{pH} 8.0$; temperature $23^{\circ} \mathrm{C}$. Q.L.: Quantification limit.

\begin{tabular}{rll}
\hline Limestone content $(\mathrm{g} / \mathrm{L})$ & $\begin{array}{l}\text { Final } \mathrm{Mn}^{2+} \text { concentration } \\
(\mathrm{mg} / \mathrm{L})\end{array}$ & Effluent final $\mathrm{pH}$ \\
\hline 8.3 & 8.0 & 7.7 \\
16.7 & 0.3 & 8.5 \\
20.8 & <Q.L. & 8.8 \\
\hline
\end{tabular}
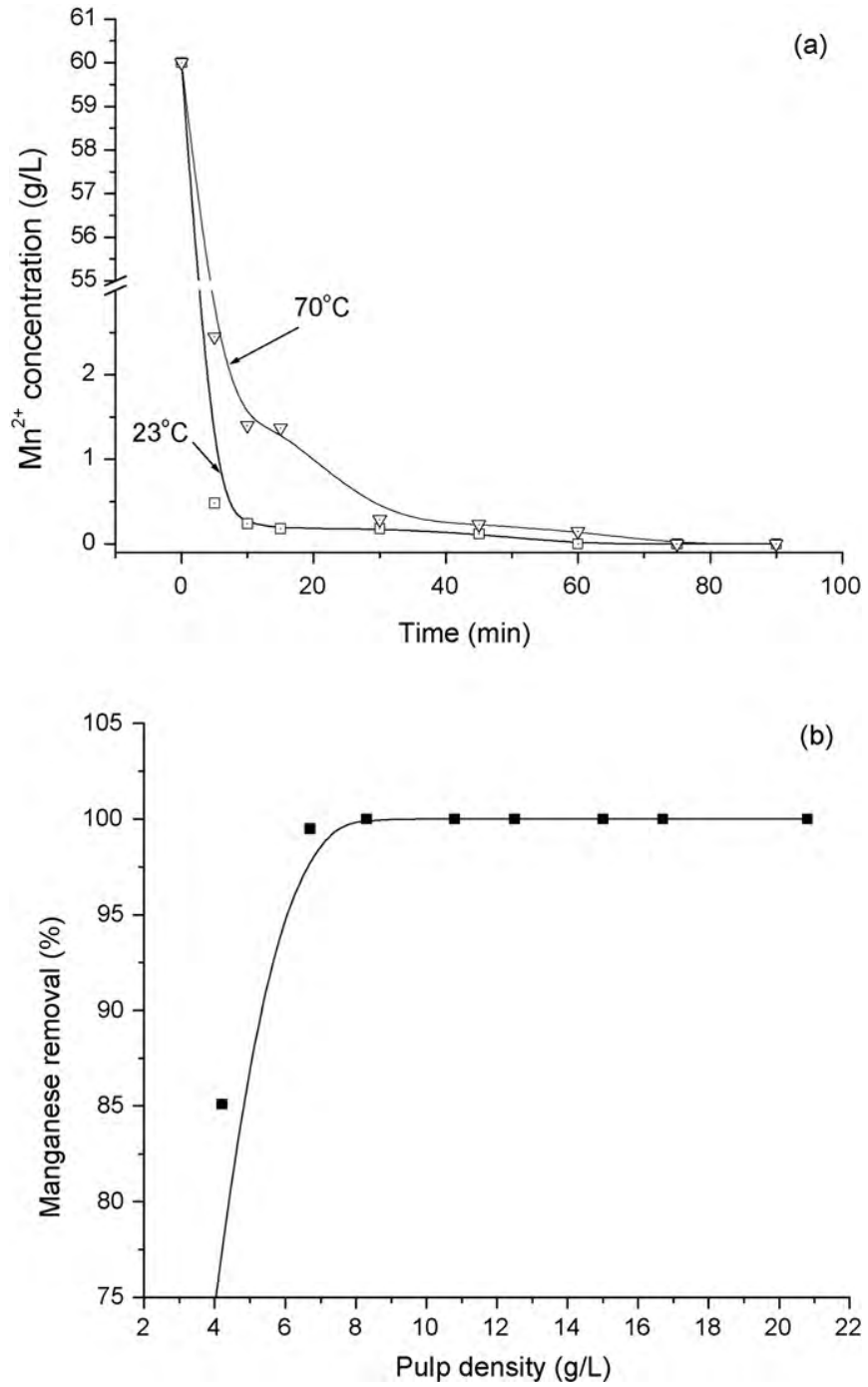

Fig. 3. Effect of limestone type (a) and pulp density (b) on the removal of manganese in batch experiments.

ments, the effect of the initial solution's pH was also assessed, since it was observed that low $\mathrm{pH}$ waters affected the performance of manganese drains which were treating acid mine drainage [10,21]. Fig. 4 shows that $20.8 \mathrm{~g} / \mathrm{L}$ limestone removes only $13 \%$ (average) of the manganese present in the mine water at its natural $\mathrm{pH}(3.3)$.

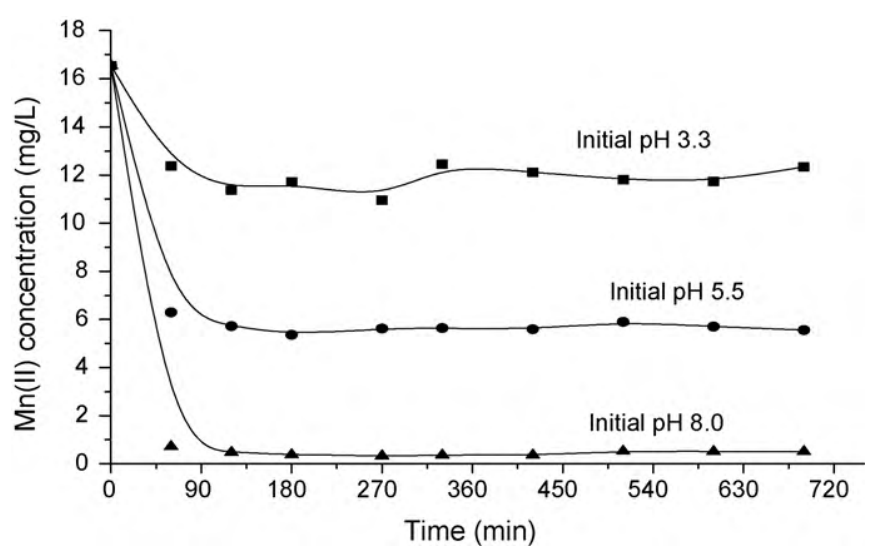

Fig. 4. Manganese concentration profiles during the continuous removal of manganese with calcite limestone. Initial concentration $16.5 \mathrm{mg} / \mathrm{L}, 20.8 \mathrm{~g} / \mathrm{L}$ pulp density, initial $\mathrm{pH} 8.0,23 \pm 2^{\circ} \mathrm{C}$. 
Table 3

Chemical analyses of mining water before and after the manganese precipitation experiment. Q.L.: Quantification limit.

\begin{tabular}{lcl}
\hline Element & Before experiment $\mathrm{pH} 8.0(\mathrm{mg} / \mathrm{L})$ & After experiment $(\mathrm{mg} / \mathrm{L})$ \\
\hline $\mathrm{Ca}$ & 74.10 & 72.85 \\
$\mathrm{Al}$ & 1.14 & 1.18 \\
$\mathrm{Fe}$ & 2.69 & 1.21 \\
$\mathrm{Mn}$ & 16.5 & 0.34 \\
$\mathrm{Zn}$ & 1.76 & $<\mathrm{Q} . \mathrm{L}$ \\
$\mathrm{K}$ & 3.93 & 4.30 \\
$\mathrm{Na}$ & 82.5 & 86.6 \\
$\mathrm{Cu}$ & 0.27 & 0.03 \\
$\mathrm{Cr}$ & 0.03 & 0.02 \\
$\mathrm{Ni}$ & 1.10 & 0.04 \\
$\mathrm{Co}$ & 0.31 & 0.01 \\
$\mathrm{Si}$ & 4.88 & $<\mathrm{Q} . \mathrm{L}$ \\
\hline
\end{tabular}

Manganese removal increases to $56 \%$ when the mine water's initial $\mathrm{pH}$ is increased to 5.0 before the addition of limestone. The manganese removal increases further to $97 \%$ when the initial $\mathrm{pH}$ is 8.0 , resulting in less than $1.0 \mathrm{mg} / \mathrm{L}$ residual manganese concentration in the final effluent. These results confirm improved manganese removal when $\mathrm{pH}$ increases as most manganese compounds are not stable at low pH [14]. Fig. 4 also shows that the process is relatively fast with metal removal in the first residence time (60 $\mathrm{min}$ ) since the manganese concentration is already below $1.0 \mathrm{mg} / \mathrm{L}$, remaining throughout the experiment, while the final $\mathrm{pH}$ reaches the 8.3-8.5 range. These results are consistent with the work of Thornton [10], who studied the treatment of mine water having an average $\mathrm{Mn}(\mathrm{II})$ concentration of $3.5 \mathrm{mg} / \mathrm{L}$. The experiments were run continuously for 495 days, being the manganese concentration reduced to $0.49 \mathrm{mg} / \mathrm{L}$ and the $\mathrm{pH}$ increased from 6.4 to 7.6. A black film coated the limestone which was ascribed to the likely presence of manganese-oxidizing microorganisms in that system. Discussing the effectiveness of limestone beds to remove manganese, Rose et al. [14] analyzed a series of experiments treat-

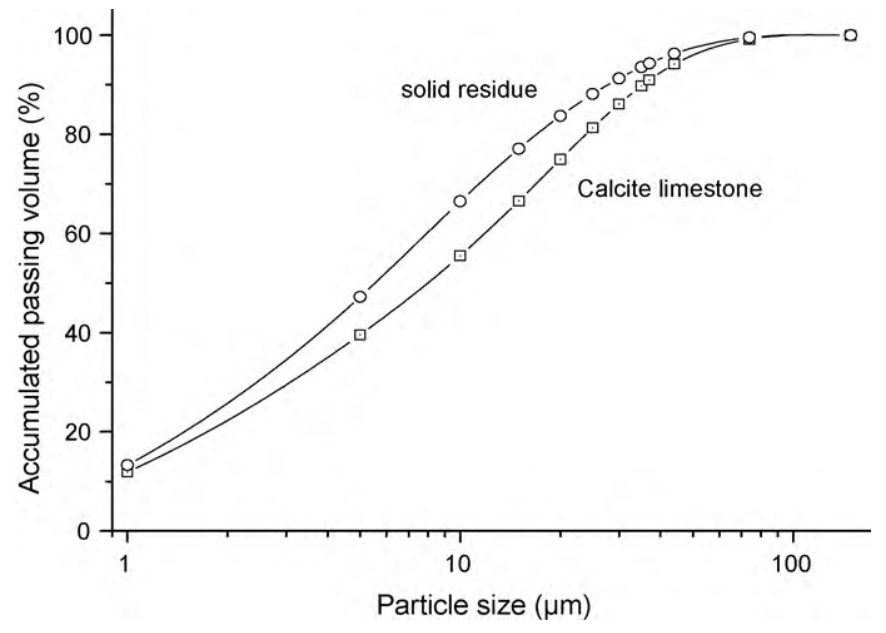

Fig. 5. Particle size distributions before and after manganese removal. Calcite limestone, $\mathrm{pH} 8.0$, continuous manganese removal, $16.5 \mathrm{mg} / \mathrm{L}, 60 \mathrm{~min}$ residence time, temperature $23 \pm 2{ }^{\circ} \mathrm{C}$.

ing AMD with manganese concentrations ranging from 5 to $30 \mathrm{mg} / \mathrm{L}$ and observed that most of these systems were able to reduce the manganese concentration to less to $1 \mathrm{mg} / \mathrm{L}$. These results clearly show that increasing the $\mathrm{pH}$ of manganese-affected wastewater has a beneficial effect on manganese extraction, regardless if synthetic solutions or mine water is treated. This reinforces the idea that manganese removal should follow a previous step where the $\mathrm{pH}$ is increased; some metals are precipitated before limestone addition.

One of the reasons for the poor performance observed with the mine water would be the armoring effect [22] of the limestone surface as several works have shown that precipitation of iron and aluminum compounds on the limestone surface reduces its dissolution. However, as shown in Table 3, the mine water, after $\mathrm{pH}$
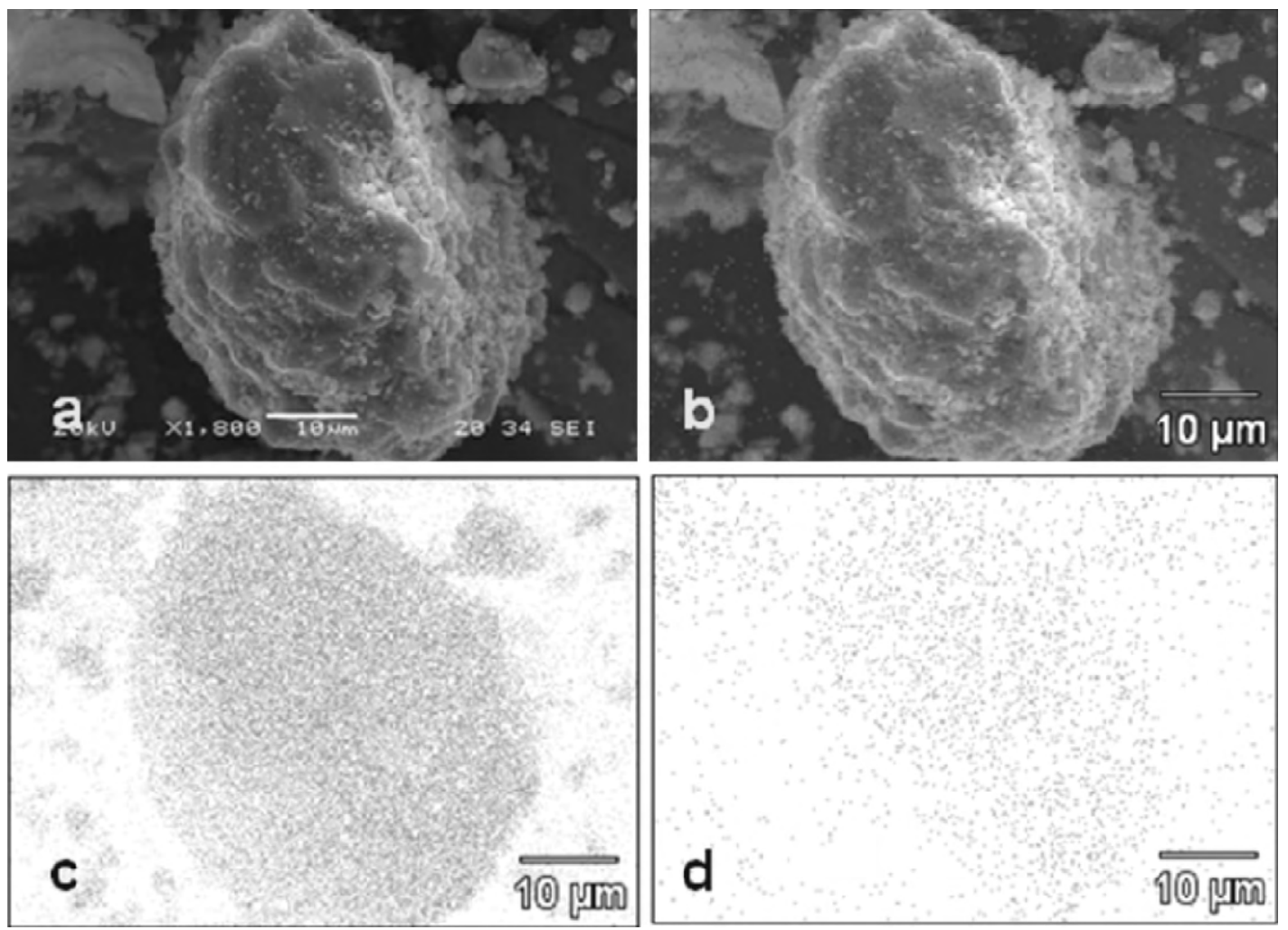

Fig. 6. SEM micrograph of a limestone particle (a) and X-ray energy dispersive spectra element distribution of (b) manganese, (c) calcium and (d) sulfur on the particle. 

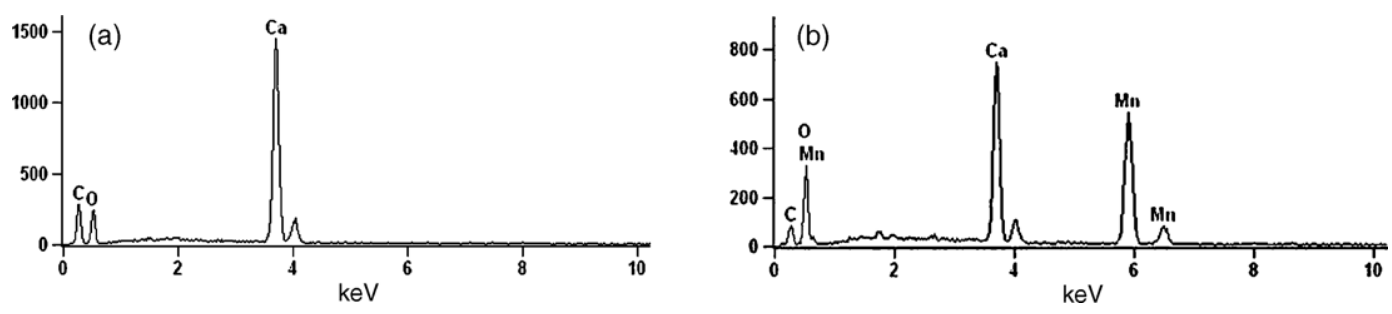

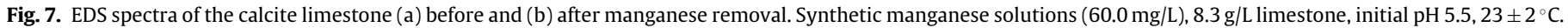

correction and before limestone addition, has a low concentration of these elements. It also shows that the manganese concentration was reduced from 16.5 to $0.3 \mathrm{mg} / \mathrm{L}$ and the other heavy metals concentration is even lower after contacting with limestone. Interestingly, the calcium concentration did not increase suggesting a small amount of limestone dissolution as observed elsewhere [10], which is supported by a decrease in the particle size (Fig. 5). The sample $\mathrm{d}_{50}$ was reduced from 8.0 to $5.5 \mu \mathrm{m}$ with a concomitant increase of the specific surface area from 3.4 to $4.3 \mathrm{~m}^{2} / \mathrm{g}$. The stability of the Mn carbonate system is currently being addressed.

To gain further insights on the limestone interaction with the mine water, X-ray energy dispersive spectra of manganese, calcium and sulfur were produced with the residues of the continuous experiments (Fig. 6). For the particle shown in Fig. 6a, Fig. 6b depicts the manganese mapping (dots); while those of calcium and sulfur are presented in Fig. $6 \mathrm{c}$ and d. It can be noticed that calcium covers the whole surface of the calcite limestone, as expected, while manganese is spread over the limestone grains and it is not concentrated in any region of the different limestone particles. Although sulfur concentration in the limestone surface (Fig. 6d) is lower than that of calcium (Fig. 6c), calcium sulfate precipitation on the limestone surface would likely account for the lower manganese removal observed in the experiments with the mine water as compared to those performed with synthetic solutions. Notwithstanding, the armoring effect produced by the presence of sulfur on the limestone surface requires further investigation.

\subsection{Manganese species on the calcite surface}

The interaction of manganese and calcium carbonate was studied with the material produced in the batch experiments using synthetic solutions, since a higher removal of manganese was observed. Firstly, SEM-EDS was applied to characterize the limestone particles before and after manganese removal. It showed no heavy metal on the solid limestone before the experiment, since only carbon, oxygen and calcium were observed in the EDS spectrum (Fig. 7a). In the batch experiments, the presence of manganese on the surface of the calcite limestone is readily seen (Fig. 7b) after contact with the manganese-containing solution. Following, these materials were characterized by infrared spectroscopy. Due to the low manganese concentration on the limestone surface, attenuated total reflectance (ATR) was applied so that the identification of the manganese species could be accomplished. ATR permits the identification of functional groups on the surface of the mineral particle, especially surface complexation and changes on the polar functional groups [23]. Fig. 8 presents the spectra of synthetic manganese carbonate, the limestone sample, and the residues of both batch and continuous manganese removal experiments. Characteristic absorption bands ascribed to calcite limestone are observed at $712-713 \mathrm{~cm}^{-1}$ in all samples, irrespective of the presence of manganese. Manganese carbonate presents an absorption band at $724 \mathrm{~cm}^{-1}$, which is consistent with the findings of Nassrallah-Aboukais et al. [24] who observed bands at 725 and $727 \mathrm{~cm}^{-1}$ assigned, respectively, to synthetic and natural $\mathrm{MnCO}_{3}$ (rhodochrosite) during manganese precipitation on cal-
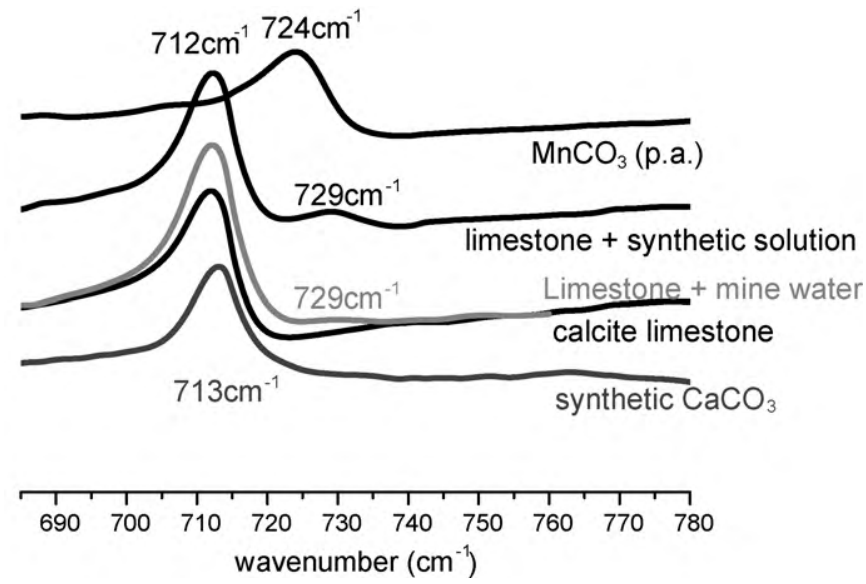

Fig. 8. ATR-FTIR spectra of different solid materials before and after manganese removal.

cium carbonate. Fig. 8 also shows a weak band at $729 \mathrm{~cm}^{-1}$ (which is $2 \mathrm{~cm}^{-1}$ higher than that observed for rhodochrosite [24]) that is proposed to be ascribed to an manganese carbonate phase formed on the surface of the calcite limestone. The shift on band position as compared as the bulk $\mathrm{MnCO}_{3}$ would be derived from the effect of the calcium atoms on the manganese carbonate bonds. This type of shift has also been observed in different adsorption systems $[25,26]$.

The mechanisms of manganese removal may include occlusion, surface adsorption, or trace phase formation [27]. An insight on that may be offered by the analysis of the surface charge of the limestone particles. Fig. 9 depicts zeta potential measurements of both the raw and manganese-containing limestone. It can be seen that the $\mathrm{pH}_{\mathrm{pzc}}$ of the raw sample is 9.8 , which is consistent with the range observed in literature $[28,29]$; a result of the nature of the potential determining ions, $\mathrm{Ca}^{2+}$ and $\mathrm{CO}_{3}{ }^{2-}$ [30]. Many researchers have

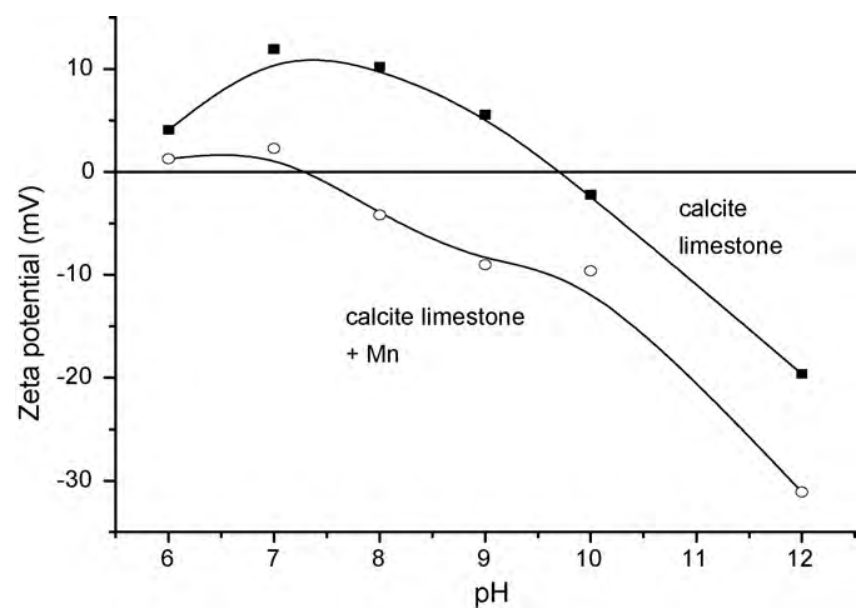

Fig. 9. Zeta potential of calcite limestone $\left(\mathrm{CaCO}_{3}\right)$ in the absence and presence of adsorbed manganese. Temperature $20^{\circ} \mathrm{C}, 5 \%$ solids pulp density. 
proposed models for the calcite mineral-aqueous solution interface and a review in this topic is beyond the scope of the present work. Nevertheless, the presence of manganese on the limestone surface decreases the $\mathrm{pH}_{\mathrm{pzc}}$ to 7.2 suggesting chemical adsorption. Considering the $\mathrm{pH}$ of the system at the end of the experiment (around 9.0), it is expected that the limestone surface would be positively charged. Additionally, a speciation diagram using manganese hydroxy-complex formation constants available in the NIST database [31] shows the predominance of aqueous $\mathrm{Mn}^{2+}$ and $\mathrm{MnOH}^{+}$in the $\mathrm{pH}$ range of manganese removal. Therefore, a physical adsorption mechanism would not explain the removal process, supporting the chemical adsorption mechanism. It is interesting that a study on rhodocrosite $\left(\mathrm{MnCO}_{3}\right)$ surface properties has determined the $\mathrm{pH}_{\mathrm{pzc}}$ of that compound as 7.4 [32] which is similar to the value observed in the present work for the Mn-containing limestone. Comparing the removal efficiency of limestone-sandstone mixtures with that of limestone alone, Ghaly et al. [16] stated that the former performs better than the latter for the removal of iron from AMD, due to the more negative surface charge of sandstone [20]. However, the authors did not notice any improvement in the removal of manganese with that mixture, which is consistent with the findings of the present work.

The interaction between manganese and limestone is complex. Although manganese carbonate would be expected in the presence of the anion, the formation of oxides is the rule. Even under those conditions where the water presented a significant concentration of carbonates, manganese oxides were suggested as the predominant species, favored by highly dissolved oxygen concentrations (forced aeration) as well as high $\mathrm{pH}$ [33], while carbonates were frequent only at high activities of dissolved carbon dioxide [15]. In this regard, when carbonate dissolution provided high calcium concentrations, kutnahorite $\left(\mathrm{CaMn}\left(\mathrm{CO}_{3}\right)_{2}\right)$ was precipitated [4] as geochemical modeling predicts that some mine water would be supersaturated with respect to this mineral. The formation of oxides over carbonates can also be partially ascribed to the presence of manganese-oxidizing bacteria in many studies $[4,11,16]$. Likely, the time scale of the experiments may play a key role, since manganese removal experiments in biotic systems last longer (3 months, for instance [16]) than those performed in the present work. Previous studies of $\mathrm{Mn}^{2+}$ adsorption on calcite indicate that manganese was adsorbed at concentrations below those defined by the solubility product of $\mathrm{MnCO}_{3}$. However, McBride [34] as well as Franklin and Morse [35] studied the interaction of $\mathrm{Mn}^{2+}$ with the surface of calcite in dilute aqueous solutions and proposed a precipitation reaction at high manganese concentrations, supported by electron spin resonance (ESR) studies. The results of the present work suggest manganese was not electrostatically adsorbed but instead was substituting for calcium on the limestone surface as proposed by Pingtore et al. [27].

\section{Conclusions}

Limestone powder was effective in removing manganese from both synthetic and mine waters. The results showed that both fine grinding as well as the initial water $\mathrm{pH}$ defines the effective manganese removal. For synthetic solutions, up to $155 \mathrm{mg} / \mathrm{L}$ manganese could be removed in $60 \mathrm{~min}$ for an initial pH of 5.5 and $8.3 \mathrm{~g}$ $\mathrm{CaCO}_{3} / \mathrm{L}$, reaching final concentrations below $1.0 \mathrm{mg} / \mathrm{L}$. The removal of manganese from mining waters $(16.5 \mathrm{mg} / \mathrm{L})$ was more difficult, requiring an initial $\mathrm{pH}$ of 8.0 and a higher limestone concentration $(20.8 \mathrm{mg} / \mathrm{L})$, likely to the deleterious effect of calcium sulfate armoring on the limestone surface. Manganese was chemically adsorbed without significant oxidation as suggested by AFT-IR. Manganese removal with limestone should therefore follow a neutralization step to increase the effluent $\mathrm{pH}$ so that efficient metal removal can be accomplished.

\section{Acknowledgements}

This work was supported by the Brazilian research funding agencies FINEP, FAPEMIG and CNPq. The CAPES and CNPq scholarships to Adarlene M. Silva and Versiane A. Leão are also gratefully acknowledged.

\section{References}

[1] USEPA, "Drinking Water Health Advisory for Manganese," U.S. Environmental Protection Agency Office of Water, Washington, DC EPA-822-R-04-003, 2004.

[2] K.L. Johnson, P.L. Younger, Rapid manganese removal from mine waters using an aerated packed-bed bioreactor, Journal of Environmental Quality 34 (3) (2005) 987-993.

[3] I.A. Katsoyiannis, A.I. Zouboulis, Biological treatment of $\mathrm{Mn}(\mathrm{II})$ and $\mathrm{Fe}(\mathrm{II})$ containing groundwater: kinetic considerations and product characterization, Water Research 38 (2004) 1922-1932.

[4] S.M. Bamforth, D.A.C. Manning, I. Singleton, P.L. Younger, K.L. Johnson, Manganese removal from mine waters-investigating the occurrence and importance of manganese carbonates, Applied Geochemistry 21 (8) (2006) 1274-1287.

[5] B.M. Tebo, H.A. Johnson, J.K. McCarthy, A.S. Templeton, Geomicrobiology of manganese(II) oxidation, Trends in Microbiology 13 (9) (2005) 421-428.

[6] J.M. Hammarstrom, P.L. Sibrell, H.E. Belkin, Characterization of limestone reacted with acid-mine drainage in a pulsed limestone bed treatment system at the Friendship Hill National Historical Site, Pennsylvania, USA, Applied Geochemistry 18 (11) (2003) 1705-1721.

[7] Q. Sun, L.M. McDonald Jr., J.G. Skousen, Effects of armoring on limestone neutralization of AMD, in: 2000 West Virginia Surface Mine Drainage Task Force Symposium, Morgantown, WV, 2000, pp. 1-10.

[8] H.A. Aziz, P.G. Smith, The influence of $\mathrm{pH}$ and coarse media on manganese precipitation from water, Water Research 26 (6) (1992) 853-855.

[9] H.A. Aziz, P.G. Smith, Removal of manganese from water using crushed dolomite filtration technique, Water Research 30 (2) (1996) 489-492.

[10] F.C. Thornton, Manganese removal from water using limestone-filled tanks, Ecological Engineering 4 (1) (1995) 11-18.

[11] C.A. Cravotta III, Laboratory and field evaluation of limestone dissolution in passive systems for neutralization of acidic mine drainage, in: 2006 West Virginia Surface Mine Drainage, West Virginia, USA, 2003, pp. 1-2.

[12] H.A. Aziz, M.S. Yusoff, M.N. Adlan, N.H. Adnan, S. Alias, Physico-chemical removal of iron from semi-aerobic landfill leachate by limestone filter, Waste Management 24 (4) (2004) 353-358.

[13] M.A. Ali, D.A. Dzombak, Competitive sorption of simple organic acids and sulfate on goethite, Environmental Science \& Technology 30 (4) (1996) 1061-1071.

[14] A.W. Rose, B. Means, P.J. Shah, Methods for passive removal of manganese from acid mine drainage, in: 2003 West Virginia Surface Mine Drainage, West Virginia, USA, 2003, pp. 1-12.

[15] J.D. Hem, C.J. Lind, Chemistry of manganese precipitation in Pinal Creek, Arizona, USA: a laboratory study, Geochimica et Cosmochimica Acta 58 (6) (1994) 1601-1613.

[16] A.E. Ghaly, M.A. Kamal, R. Cote, Effect of temperature on the performance of limestone/sandstone filters treating landfill leachate, American Journal of Environmental Sciences 3 (1) (2007) 11-18.

[17] USEPA, "Calcium Carbonate Dissolution Rate in Limestone Contactors," U.S Environmental Protection Agency, Washington, DC EPA/600/R-95/068, 1995.

[18] R.D. Letterman, C.T. Driscoll, M. Haddad, H.A. Hsu, Limestone bed contactors for control of corrosion at small water utilities, U.S. Environmental Protection Agency, Syracuse, N.Y. EPA/600/2-86/099, 1999.

[19] S.S. Potgieter-Vermaak, J.H. Potgieter, P. Monama, R. Van Grieken, Comparison of limestone, dolomite and fly ash as pre-treatment agents for acid mine drainage, Minerals Engineering 19 (5) (2006) 454-462.

[20] Q. Sun, L.M. McDonald Jr., J.G. Skousen, 2000. Effects of armoring on limestone neutralization of AMD, 2000 West Virginia Surface Mine Drainage Task Force Symposium, Morgantown, WV, 1-10.

[21] C.A. Cravotta IIII, M.K. Trahan, Limestone drains to increase $\mathrm{pH}$ and remove dissolved metals from acidic mine drainage, Applied Geochemistry 14 (5) (1999) 581-606.

[22] J.M. Soler, M. Boi, J.L. Mogollón, J. Cama, C. Ayora, P.S. Nico, N. Tamura, M. Kunz, The passivation of calcite by acid mine water. Column experiments with ferric sulfate and ferric chloride solutions at pH 2, Applied Geochemistry 23 (12) (2008) 3579-3588.

[23] S.J. Parikh, J. Chorover, FTIR spectroscopic study of biogenic Mn-oxide formation by Pseudomonas putida GB-1, Geomicrobiology Journal 22 (5) (2005) 207-218.

[24] N. Nassrallah-Aboukais, A. Boughriet, L. Gengembre, A. Aboukais, Manganese(II)/vaterite/water systems-spectroscopic and thermodynamic study, Journal of the Chemical Society-Faraday Transactions. 94 (16) (1998) 2399-2405.

[25] A.S. Ibrado, D.W. Fuerstenau, Infrared and X-ray photoelectron spectroscopy studies on the adsorption of gold cyanide on activated carbon, Minerals Engineering 8 (4-5) (1995) 441-458.

[26] V.A. Leão, G.L. Lukey, J.S.J. van Deventer, V.S.T. Ciminelli, The dependence of sorbed copper and nickel cyanide speciation on ion exchange resin type, Hydrometallurgy (2001). 
[27] N.E. Pingitore, M.P. Eastman, M. Sandidge, K. Oden, B. Freiha, The coprecipitation of manganese(II) with calcite: an experimental study, Marine Chemistry 25 (2) (1988) 107-120.

[28] M.F. Salinas-Nolasco, J. Mendez-Vivar, V.H. Lara, P. Bosch, Passivation of the calcite surface with malonate ion, Journal of Colloid and Interface Science 274 (1) (2004) 16-24.

[29] D.W. Thompson, P.G. Pownall, Surface electrical properties of calcite, Journal of Colloid and Interface Science 131 (1) (1989) 74-82.

[30] S.L.S. Stipp, Toward a conceptual model of the calcite surface: hydration, hydrolysis, and surface potential, Geochimica et Cosmochimica Acta 63 (19-20) (1999) 3121-3131.

[31] A.E. Martel, R.M. Smith, NIST Critically Selected Stability Constants of Metals Complexes, 7th ed., The National Institute of Standards and Technology-NIST, Gaithersburg, 2003.
[32] S. Song, S, Lu, Hydrophobic flocculation of fine hematite, siderite, and rhodochrosite particles in aqueous solution, Journal of Colloid and Interface Science 166 (1) (1994) 35-42.

[33] A.L. Foster, G.E. Brown, G.A. Parks, X-ray absorption fine structure study of $\mathrm{As}(\mathrm{V})$ and $\mathrm{Se}(\mathrm{IV})$ sorption complexes on hydrous Mn oxides, Geochimica et Cosmochimica Acta 67 (11) (2003) 1937-1953.

[34] M.B. McBride, Chemisorption, Precipitation of $\mathrm{Mn}^{2+}$ at $\mathrm{CaCO}_{3}$ surfaces, Soil Science Society of America Journal 43 (4) (1979) 693-698.

[35] M.L. Franklin, J.W. Morse, The interaction of manganese(II) with the surface of calcite in dilute solutions and seawater, Marine Chemistry 12 (4) (1983) 241-254. 